\title{
Birsen Ekim Özen'in Çelebi Zinciri Adlı Eserinin Değerler Eğitimi ve Türkçe Ders Kitaplarında Yer Alan Temalara Uygunluk Açısından İncelenmesi ${ }^{1}$
}

\author{
Tuğrul Gökmen ŞAHİN \\ Arş. Gör., İnönü Üniversitesi, \\ Eğitim Fakültesi, Türkçe ve Sosyal Bilimler Eğitimi Bölümü, \\ Türkçe Eğitimi Ana Bilim Dalı \\ tugrul.sahin@inonu.edu.tr \\ Orcid ID: https://orcid.org/0000-0003-2107-9670 \\ Özcan BAYRAK \\ Prof. Dr., Firat Üniversitesi, \\ Eğitim Fakültesi, Türkçe ve Sosyal Bilimler Eğitimi Bölümü, \\ Türkçe Eğitimi Ana Bilim Dalı \\ ozcanbayrak@firat.edu.tr \\ Orcid ID: https://orcid.org/0000-0002-3392-5021
}

\begin{abstract}
Öz
Yerel ögelerden beslenerek, evrensel sulara dökülen ve toplumun maddi manevi bütün unsurları olarak değerlendirebileceğimiz değerleri; Birsen Ekim Özen'in Çelebi Zinciri adlı eserinde incelemek adına bu çalışma yapılmıştır. Bu çalışmadan hareketle çocuk kitapları aracılı̆̆ıyla değer aktarımının önemine dikkat çekmek amaçlanmıştır. Bu bağlamda söz konusu çalışma nitel araştırma yöntemine dayalı doküman incelemesi ile gerçekleştirilmiş olup çalışmanın veri kaynağını Çelebi Zinciri isimli kitap oluşturmaktadır.
\end{abstract}

Eser; adalet, dostluk, dürüstlük, öz denetim, sabır, saygı, sevgi, sorumluluk, vatanseverlik ve yardımseverlik açısından incelenmiştir. Veri analizinde içerik analizi kullanılmıştır. Bulgular kısmında eserde hangi değerin hangi sayfada bulunduğu, doğrudan alıntı yapılarak gösterilmiştir. Gerekli uzman görüşleri alınması, kitabın içinde Millî Eğitim Bakanlığının benimsediği 10 kök değere uygun ögelerin tespit edilmesi; yazarın Çağdaş Çocuk Edebiyatı'nın sevilen bir yazarı ve kitabın başka bir çalışmada yer almamış olması bu eserin çalışılma nedenidir. Yazarın eserinde; çocuk edebiyatına, çocuklara değer aktarma sürecine

\footnotetext{
${ }^{1}$ Makale Geliş/Kabul Tarihi: 20.05.2020 / 03.10.2020

Künye Bilgisi: Şahin, T.G. ve Bayrak, Ö. (2020). Birsen Ekim Özen 'in Çelebi Zinciri Adlı Eserinin Değerler Eğitimi ve Türkçe Ders Kitaplarında Yer Alan Temalara Uygunluk Açısından Incelenmesi. Kahramanmaraş Sütçü Imam Üniversitesi Sosyal Bilimler Dergisi, 17 (2), 775-798. DOI: 10.33437/ksusbd.755557
} 
katkısının olduğu ve 10 kök değerin tamamına yer verdiği görülmüsstür. $\mathrm{Bu}$ doğrultuda Türkçe ders kitaplarında yer alan temalarda yazarın eserine yer verilebileceği düşünülmektedir.

Anahtar Kelimeler: Değerler Eğitimi, Çocuk Kitapları, Çelebi Zinciri, Birsen Ekim Özen, Değer Aktarımı.

\title{
A Revıew on Çelebi Zinciri by Birsen Ekim Özen for Values Educatıon and its Complıance with Themes in Turkısh Course Books
}

\begin{abstract}
This study was carried out to examine the values that we can consider as all material and moral elements of the society that are fed by local elements and poured into universal waters, in Çelebi Zinciri by Birsen Ekim Özen. It was aimed to draw attention to the importance of value transfer through children's books. In this context, this study was carried out with document analysis based on qualitative research method and the data source is the book named Çelebi Zinciri. The book was examined in terms of justice, friendship, honesty, self-control, patience, respect, love, responsibility, patriotism and helpfulness. Content analysis was used in data analysis. That which value is found on which page in the book was shown by direct quoting in the Findings section. The reasons for making a review on this book are having been got the necessary expert opinions, determined the elements that are in accordance with the 10 root values adopted by the Ministry of National Education and its taking no part in another study. In the author's book, it has been observed that it contributes to children's literature, the process of transferring value to children and includes all ten root values. Accordingly, it is thought that this book can take part in the themes in the Turkish textbooks.
\end{abstract}

Keywords: Values Education, Children's Books, Çelebi Zinciri, Birsen Ekim Özen, Value Transfer. 


\section{GİRIŞ}

Dünyada 18. yüzyıl sonrasında ülkemizde ise 19. yüzyıldaki kaynaklarda çocukluk kavramı karşımıza çıkmaktadır. Hâliyle çocukluk ve çocuk kavramının uzun yıllar göz ardı edilmiş olması çocuk edebiyatı kavramının oluşmasını da epey geciktirmiştir. O zamana kadar yazılan eserlerde çocuk figürü az olmakla birlikte, Yer aldıkları sınırlı eserlerde de küçük insan motifiyle kendilerine yer açtıklarını görmekteyiz. Sonrasında çocuğa olan bakış açısı değişimi çocukluğun ayrı bir yaşam dönemi olduğunu kabul ettirmiş beraberinde çocuğun ihtiyaçlarının da farklı olduğu gerçeğini ortaya çıkarmıştır. Ülkemizde ise bu değişimi kabul edişin özellikle Tanzimat sonrasında olduğunu görmekteyiz. Toplumumuzdaki çocuk algısının Batılılaşma hareketiyle koşut bir çizgide ilerlediği (Şimşek, 2016: 16) görülmektedir. Çocuk ve çocukluk kavramlarının yerini sağlamlaştırması, beraberinde çocuk edebiyatı ihtiyacını doğurmuş ve çocuk edebiyatı kavramı hayatımıza girmiştir. Bu noktada çocuk edebiyatının hemen kabul görmesi söz konusu olmamakla birlikte (Ataç, 1970: Akt. Şirin, 2007: 54) sonrasında çocuk edebiyatının öncelikle yalınlık, çocuk gerçekliği ve çocuğa görelik (Şirin, 2007: 19) olarak farklı bir edebiyat türü şeklinde kabul görmesi gerçekleşmiştir. Günümüzde çocuk edebiyatının bir geçiş dönemi edebiyatı olduğu (Şirin, 2007: 4) kanıksanmış olup çocuklara yönelik icra edilen edebiyatın da bütün edebiyat niteliklerini içermesi gerektiği anlaşılmıştır.

Çocuklar için yazılan edebi eserler, farklı türde ve temada karşımıza çıkmaktadır. Bu noktada yazardan beklenen; çocuğa hayatın ve insanın farklı yönlerini gösterip hayattan birtakım kesitler sunması, kahramanların davranışlarıyla bireye gizil bir yaşam tecrübesi kazandırmasıdır. Bu nedenle edebî eserlerin çocuk eğitimi için kullanılır olması sadece bir ihtiyaç değil, aynı zamanda bir gerekliliktir. Çünkü gerek devletin gerekse toplumun bireylerde bulunmasını istediği değerler ve davranışlar vardır. Toplumun geneli tarafından benimsenen ortak kabuller kişinin kendi iç huzurunu yakalamasını sağlamanın yanında bireyleri ortak duygular etrafında birleştirerek toplumsal birlik ve beraberliği kurması (Kumbasar, 2011: 22) açısından da önemlidir. $\mathrm{Bu}$ davranışların kazandırılmasında çocukluk döneminin kritik dönem olduğu göz önünde bulundurulmalıdır (Güler, 2014: 8). Bu kritik dönemde geleceğin yetişkinlerini eğitirken aynı zamanda değerler yönünden kişiliklerini donanımlı hâle getirmek (Gönen, 2017: 35) gerekir. Zira değerler bir toplumu ayakta tutan önemli dinamiklerden biridir. Bu nedenle kültürel değerlerin, görgü ve ahlak kurallarının, çocuk edebiyatı eserlerine konu olmasına gayret gösterilirse çocuk, yaşadığ̣ topluma daha rahat uyum gösterir (Aktürk, 2012: 13).

Toplum için değerleri bu denli önemli kılan davranışlara yol gösteren, rehberlik eden inançlar ve kurallar ya da daha öz bir ifadeyle insanın eylem ve söylemlerine dayanarak teşkil eden ölçütler (Şimşek, 2016: 330) olmasındandır. 
Aynı zamanda değer kavramı insanı diğer canlılardan ayıran, insana insani vasıfları kazandıran temel özellikler ve davranışlara yön veren inançlar (Ulusoy ve Dilmaç 2016: 16) olarak karşımıza çıkmaktadır. Bireylerde değer sisteminin oluşması kendi kendine olan bir süreç değildir. Bireyin değer öğretimi sürecinde desteklenmesi gerekmektedir. Elbette değerlerin kazanılmasında birçok faktörün (okul, aile, arkadaş çevresi) etkisi vardır. Ancak bu yolda kullanılabilecek en önemli araçlardan biri sanat unsurları ve özellikle de edebiyattır. Bu nedenle çocuk kitapları çocuğa uygun olmalı ancak çocukça, sadece onu eğlendirmemeli aynı zamanda eğitmeli, olmamalı; çocuğun kültür gelişimine, düş gücünün gelişmesine, okuma alışkanlığı kazanmasına katkı sağlayacak bir nitelikte olmalı (Dilidüzgün, 2007: 18) ve yaşadığı topluma dair değerleri çocuğa aktarmalıdır.

Değerler eğitiminin çocuklara nasıl aktarılması gerektiği çok zor bir durumdur. Somut işlemler döneminde olan çocuk, sayg1, dürüstlük, sevgi gibi tamamen soyut olan kavramları anlayıp içselleştirmekte zorlanmaktadır. $\mathrm{Bu}$ noktada çocuk edebiyatının varlığı değer aktarımı ile ilgili en önemli yükü sirtlamaktadır. Yaş grubuna uygun olarak tercih edilecek masallar, fabllar, hikâyeler ya da romanlar hele ki usta ellerden çıkmışsa çocuğu değerler noktasında donanımlı hâle getirebilir, karakterlerle duygudaşlık kuran çocuk çıkacağı hayali yolculuklarda toplumsal değerleri benimseyebilir. Bu nedenle türü ne olursa olsun çocuk edebiyatı ürünlerinin ele aldıkları konular, anlatım teknikleri ve kişi kadrosu bakımından çocukların renkli ve masum dünyasını olumlu yönde geliştirmeye, onlara birtakım değerleri ve doğru davranış kalıplarını kazandırmaya yönelik (Arseven, 2005: 51) olması gerektiği göz ardı edilmemelidir.

Değerler eğitimiyle ilgili her geçen gün farklı çalışmaların yapılması ve bu alanda birçok akademik yayının olması, değerler eğitimine verilen önemi ortaya koymaktadır. MEB'in değerler eğitimi kapsamında yayınladığı yönergeler, yaptığı çalışmalar, etkinlikler, projeler oldukça önemlidir. Bu noktada Değerler Eğitimi Merkezi (DEM) tarafından birinci ve ikincisi 26-28 Kasım 2004, 16-18 Kasım 2012 tarihinde İstanbul'da, üçüncüsü ise 5-6 Nisan 2018 tarihinde Zonguldak'ta düzenlenen kongreler yapılmıştır. Yine DEM tarafindan 2003 yılından beri yayınlanan uluslararası katılımlı hakemli bir dergi olan Değerler Eğitimi Dergisi (DED)'de alanda oldukça önemlidir.

Her toplumun kendine özgü değerler sisteminin olması değerlerle ilgili bir standarttan söz ettirmeyi zorlaştırmaktadır. Hem kültürü hem toplumsal yapıyı şekillendiren değerler sistemi, insanlığın var oluşuyla aynı geçmişe sahiptir diyebilinirken değer aktarımı geçmişten bugüne aynı şekilde devam ediyor denilemez. Geçmişte kabul görmüş bir değer günümüzde benimsenmeyebilir. Yahut günümüzde toplum tarafindan kabul görmüş bir değer, gelecekte değişime uğrayabilir ya da tamamen ortadan kalkabilir. Bu nedenle çalışma kapsamında 
incelenen kitapta yer alan değerler ele alınırken MEB'e bağlı kalmak uygun görülmüş ve Çelebi Zinciri adlı eser aşağıda verilen 10 kök değer açısından incelenmiştir.

Tablo 1. 2017'de Güncellenen, Talim ve Terbiye Kurulunca Yayınlanan Müfredatta Yer Alan Değerler ve Değerlerle İlişkili Bazı Tutum ve Davranışlar

\begin{tabular}{|c|l|}
\hline Değerler & \multicolumn{1}{|c|}{ Değerlerle İlgili Bazı Tutum ve Davranışlar } \\
\hline Adalet & Adil olma, eşit davranma, paylaşma... \\
\hline Dostluk & $\begin{array}{l}\text { Diğerkâmlı, güven duyma, anlayışlı olma, dayanışma, } \\
\text { sadı olma, vefalı olma, yardımlaşma... }\end{array}$ \\
\hline Dürüstlük & $\begin{array}{l}\text { Açık ve anlaşılır olma, doğru sözlü olma, güvenilir olma, } \\
\text { sözünde durma... }\end{array}$ \\
\hline Öz denetim & $\begin{array}{l}\text { Davranışlarını kontrol etme, davranışlarının sorumluluğunu } \\
\text { üstlenme, öz güven sahibi olma, gerektiğinde özür dileme... }\end{array}$ \\
\hline Sabır & Azimli olma, tahammül etme, beklemeyi bilme... \\
\hline Sayg1 & $\begin{array}{l}\text { Alçakgönüllü olma, başkalarına kendine davranılmasını } \\
\text { istediği şekilde davranma, diğer insanların kişiliklerine } \\
\text { değer verme, muhatabının konumunu, özelliklerini ve } \\
\text { durumunu gözetme }\end{array}$ \\
\hline Sevgi & $\begin{array}{l}\text { Aile birliğine önem verme, fedakârlık yapma, güven duyma, } \\
\text { merhametli olma, vefalı olma... }\end{array}$ \\
\hline Sorumluluk & $\begin{array}{l}\text { Kendine, çevresine, vatanına, ailesine karşı sorumlu olma; } \\
\text { sözünde durma, tutarlı ve güvenilir olma, davranış̧larının } \\
\text { sonuçlarını üstlenme... }\end{array}$ \\
\hline Vatanseverlik & $\begin{array}{l}\text { Çalı̧kan olma, dayanışma, kurallara ve kanunlara uyma, } \\
\text { sadık olma, tarihsel ve doğal mirasa duyarlı olma, toplumu } \\
\text { önemseme }\end{array}$ \\
\hline Yardımseverlik & $\begin{array}{l}\text { Cömert olma, iş birliği yapma, merhametli olma, } \\
\text { misafirperver olma, paylaşma }\end{array}$ \\
\hline
\end{tabular}

10 kök değer aktarımı yapılırken her dersin içeriğine ve hazırlanan müfredata bağlı olarak metinler aracılığıyla değerlerin öğrenciyle teması sağlanır. $\mathrm{Bu}$ bağlamda Türkçe dersinde de Türkçe ders kitaplarındaki metinler önem arz etmektedir. Bu metinler aracıllğıyla 10 kök değer ve daha fazlası öğrencilere aktarılır. Metinler temaya uygun olarak seçilmektedir. Türkçe Dersi Öğretim Programı'nın uygulanması sürecinde her sınıf düzeyinde 8 tema işlenmesi ön görülmüștür. Bu temalardan "Erdemler", "Milli Kültürümüz", "Milli Mücadele ve Atatürk" temalarının her sınıf düzeyinde işlenmesi zorunludur. Öğrenme öğretme sürecinde işlenmesi öngörülen temalar ve temalarda yer alacak değerler tabloda sunulmuştur (URL4, 2019). 
Tablo 2. Türkçe Dersi Öğretim Programı'nda Yer Alan Temalar ve Değerler

\begin{tabular}{|c|c|}
\hline TEMALAR & DEĞERLER \\
\hline ERDEMLER & $\begin{array}{l}\text { Ahlak, alçak gönüllülük, azim, } \\
\text { cömertlik, dayanışma, dostluk, } \\
\text { dürüstlük, güven, iyilikseverlik, } \\
\text { kardeşlik, merhamet, paylaşma, } \\
\text { sabır, sadakat, sayg1, sevgi, } \\
\text { sllayırahim, vefa, vicdanlı olmak, } \\
\text { yardımlașma }\end{array}$ \\
\hline MİLLÎ KÜLTÜRÜMÜZ & $\begin{array}{l}\text { Aile, büyüklerimiz, bayrak, dini } \\
\text { bayramlar, gelenekler, kültürel miras, } \\
\text { millî bayramlar, vatan, Türkçe, tarihi } \\
\text { eserlerimiz }\end{array}$ \\
\hline MİLLİ MÜCADELE VE ATATÜRK & $\begin{array}{l}\begin{array}{l}\text { Fedakârlık, } \\
\text { vatanseverlik }\end{array} \\
\text { millî } \quad \text { egemenlik, }\end{array}$ \\
\hline BİREY VE TOPLUM & $\begin{array}{l}\text { Ana dili, adalet, barış, dayanışma, } \\
\text { empati, eşitlik, farkliliklara saygi, } \\
\text { haram, helal misafirperverlik, } \\
\text { komşuluk ilişkileri, selamlaşma, } \\
\text { toplumsal kurallar, vatandaşlik }\end{array}$ \\
\hline OKUMA KÜLTÜRÜ & Dil sevgisi \\
\hline İLETIŞ̦iM & Aile iletişimi, insanlarla iletişim \\
\hline HAK VE ÖZGÜRLÜKLER & $\begin{array}{l}\text { Demokrasi, temel hak ve özgürlükler, } \\
\text { toplumsal cinsiyet eşitliği / adaleti, } \\
\text { yaşama hakk1 }\end{array}$ \\
\hline KİŞ̇SEL GELİŞìM & $\begin{array}{l}\text { Çalışkanlık, empati, girişimcilik, öz } \\
\text { denetim, öz eleştiri, öz güven, öz } \\
\text { sayg1, sorumluluk }\end{array}$ \\
\hline BİLİM VE TEKNOLOJİ & Girişimcilik \\
\hline SAĞLIK VE SPOR & Temizlik, adil oyun \\
\hline DUYGULAR & Bağışlama, sevgi, takdir etme \\
\hline SANAT & Yenilikçi düşünme \\
\hline VATANDAŞLIK & $\begin{array}{l}\text { Adalet, çalışma, eşitlik, paylaşma, } \\
\text { sorumluluk }\end{array}$ \\
\hline
\end{tabular}

Bu tabloda görüleceği üzere 10 kök değerin temaların işlenmesi için seçilen metinler aracılığıyla öğrenciye gizil yollarla verilmesi amaçlanır. Ders kitaplarında seçilen metinlerin nitelikli olması ve bu gizil görevi layıkıyla yerine getirmesi gerekir. $\mathrm{Bu}$ nedenle seçilen metinlerin değer aktarımı açısından 
incelenmesi ve sonrasında kitapta yer alması uygun olacaktır. Bu doğrultuda yapılan literatür taramasında değerler eğitimiyle ilgili birçok çalışmaya ulaşılmıştır. Ancak doğrudan Özen'in eserlerinde değerler eğitiminin incelendiği sadece bir çalışma bulunmaktadır. Palaz'a (2019) ait "Çocuk Edebiyatı Açısından Birsen Ekim Özen'in Eserleri ve Eserlerinde Yansıttığı Değerler Üzerinde İncelemeler" adlı bu çalışmada yazar eserleri 10 kök değerin (adalet, dostluk, dürüstlük, öz denetim, sabır, saygı, sevgi, sorumluluk, vatanseverlik, yardımseverlik) yanı sıra ilkokul Sosyal Bilgiler Öğretim Programı'ndaki (2018)' değerler (aile birliğine önem verme, bağımsızlık, barış, bilimsellik, çalışkanlık, dayanışma, duyarlılık, estetik, eşitlik, özgürlük, tasarruf) açısından da incelenmiştir. Çalışma sonucunda eserlerde en çok bilimsellik değeri tespit edilmiş olup bağımsızlık, barış, estetik ve eşitlik değerlerine hiç rastlanmamıştır.

Çalışmayla 10 kök değerin kitaplarda yer alması bakımından benzerlik teşkil eden çalışmalardan biri, değerler eğitimi açısından Necip Fazıl Kısakürek'e ait "Çile" adlı eserde kök değerlerin incelenmesi adlı yüksek lisans tezidir. Demir (2019) Çile 'deki metinleri çözümleyerek adalet, dostluk, dürüstlük, öz denetim, sabır, saygı, sevgi, sorumluluk, vatanseverlik, yardımseverlik değerlerini içermesi bakımından incelemiştir. Bu değerlerin doğrudan ya da örtük bir şekilde işlendiği tespit edilmiştir. Benzer şekilde Şahin'in (2019) Sabahattin Ali'nin eserlerinde değerler eğitimi isimli çalışması da yine 10 kök değerin tespiti üzerinedir. İncelenen eserler, değerler açısından çok zengin bir içeriğe sahip olmasalar da günümüz toplumunda eksikliğini hissetmeye başladığımız sevgi, fedakârlık ve yardımseverlik gibi duyguları, yazarın olayları ele alış tarzıyla somut bir şekilde okura yansıttığı sonucuna ulaşı1mıştır.

Aytül Akal'ın çocuk romanlarının incelenmesi, 10 kök değerin kitaplar üzerindeki incelenmesinde son dönemde yapılan bir diğer çalışmadır (Akıncı, 2019). Seçilen kitaplarda kök değerlerden hangilerinin olduğu ve bunlara ne sıklıkta yer verildiğini tespit etmek amaçlanmıştır. Kök değerler çerçevesinde incelenen kitaplarda bütün değerlere ilişkin ifadelere yer verildiği görülmüş olup özellikle sevgi değerine bağlı aile birliğine önem verme tutumu bütün kitaplarda yer almaktadır. Adalet değeri ise en az rastlanan değerdir.

Çalışmanın bir diğer boyutu Çelebi Zinciri adlı eserin Türkçe ders kitaplarında değer aktarımı amacıyla kullanılıp kullanılmadığına yöneliktir. Bu doğrultuda literatüre bakıldığında Derse'nin 2019' da yaptığı " 6 . Sınıf Türkçe Ders Kitabında Yer Alan Metinlerin Değerler Eğitimi Açısından İncelenmesi ve Öğretmen Görüşleri Bağlamında Değerlendirilmesi” isimli çalışma karşımıza çıkmaktadır. Çalışmada değerler eğitimi kavramıyla ilgili öğretmenlerin en çok hoşgörü, sevgi ve yardımseverlik değerlerinden söz ettikleri görülmüştür. Yine çalışmanın bir başka sonucu da öğretmenlerin metinlerde en çok yer verilmesini istedikleri değerin saygı değeri olduğu üzerinedir. Türkçe öğretiminde değerler eğitimi 
bağlamında Refik Halid Karay'ın hikâyelerinin analizi isimli çalışmada ise Memişoğlu (2019) söz konusu hikâyelerin Türkçe Dersi Öğretim Programı 1şığında ders kitaplarında okuma parçası olarak kullanılabilirliğini incelemiş ve kullanılabileceği sonucuna varmıştır. Ders kitaplarına öneride bulunan Şahin (2017), Cengiz Aytmatov'un Eserlerinin Değerler Eğitimi Bağlamında İncelenmesi ve Ortaokul Türkçe Ders Kitapları İçin Metin Önerileri adlı doktora tezinde Cengiz Aytmatov'un eserlerini değerler eğitimi açısından incelenmiştir. $\mathrm{Bu}$ doğrultuda ders kitaplarında olması yönünde görüş belirtmiştir.

Yapılan literatür tarama sonucuna göre Birsen Ekim Özen'in kitaplarına yönelik bir adet çalışmaya ulaşılmıştır. Ancak söz konusu çalışmada Çelebi Zinciri adlı eserin yer almamış olması ve çalışmaya konu olan bu kitapla diğer kitapları arasındaki değerler eğitimi bağını görme isteği bu çalışmanın yapılma nedenidir. Bu bağlamdan hareketle Birsen Ekim Özen'in Çelebi Zinciri adlı eserinin çocuklara değer kazandırma açısından kullanılabilecek nitelikte olup olmadığını, söz konusu eserin 10 kök değerden hangilerini içerdiğini ve Türkçe ders kitaplarında yer alan temalara uygunluğunu belirlemek çalışmanın problem durumunu oluşturmaktadır.

\section{YÖNTEM}

Çalışmada Birsen Ekim Özen'in Çelebi Zinciri adlı eseri, 10 kök değeri içermesi bakımından incelenmiştir. Bu bölümde ise araştırmanın modeli, evren ve örneklemi, verilerin toplanması ve analizi ile yorumlanması süreci hakkında bilgi verilmiştir.

\section{Araştırma Modeli}

Çalışmada nitel araştırma yöntemlerinden olan doküman inceleme yöntemi kullanılmıştır. Resmi ya da özel kayıtların toplanıp, sistemli bir biçimde tetkik edilmesi (Ekiz, 2003) olarak karşımıza çıkan doküman analizi araştırma modelinde; kaynaklarla ilgili genel tarama ve içerik analizi olmak üzere iki farklı amaç gözetilir (Karasar, 2008: 184). Bu bağlamda çalışmanın verileri içerik analizi ile değerlendirilmiştir.

\section{Çalışma Dökümanı}

Çalışma dokümanı olarak Birsen Ekim Özen'in çocuk kitapları arasından Çelebi Zinciri adlı eser seçilmiştir. Araştırmada literatür taraması yapılarak, alanla ilgili daha önceden yayınlanmış kitaplar, tezler ve makaleler taranmıştır. $\mathrm{Bu}$ sayede Çelebi Zinciri adlı eserin değer aktarımı konusundaki rolü belirlenmeye çalış1lmıştır. 


\section{Verilerin Toplanması}

Araştırmanın veri kaynaklarını Birsen Ekim Özen'in 2017 yılında yazdığ 1 Çelebi Zinciri adlı eser oluşturmaktadır. Eser, 10 kök değerden; adalet, dostluk, dürüstlük, öz denetim, sabır, sayg1, sevgi, sorumluluk, vatanseverlik, yardımseverlik açısından incelenmiştir. Eserde yer alan değerler tespit ve tasnif edilmiştir. Bu doğrultuda 10 kök değerin eserde doğrudan veya hissettirme yoluyla işlendiği görülmüş ve söz konusu değerlerin kaç kez eserde yer aldığ 1 alıntı yapılarak gösterilmiştir

\section{Verilerin Analizi}

Eser baştan sona defalarca okunmuş; MEB'in belirlediği kök değerlere göre söz konusu eserde ayrı ayrı okuma, not alma, çıkarımda bulunma, değerlendirme işlemi yapılmıştır. Her değerlendirme ile ilgili sonuçlar ayrı başlık altında toplanmış, değerlerle ilgili iletilerin nasıl verildiği ve değerlerin nasıl işlendiği tespit edilmiştir. Ardından yorumlama yapılarak sonuçlara ulaşılmıştır. Hangi değerin eserde ne şekilde işlendiği, doğrudan alıntı yapılarak gösterilmiştir.

\section{BULGULAR VE YORUM}

\section{Talim ve Terbiye Kurulunca Yayınlanan Müfredatta Yer Alan Değerler ve Değerlerle İlişkili Bazı Tutum ve Davranışlar Açısından Bulgular}

\section{Adalet Değeri}

Türkçe Sözlükte adalet kavramı; yasalarla sahip olunan hakların herkes tarafından kullanılmasının sağlanması, hak ve hukuka uygunluk, hakkı gözetmek, adalet işini uygulayan ve yerine getiren devlet kurumları, herkesin hakkına düşeni verme şeklinde tanımlanmıştır (TDK, 2019).

Adalet değeri ile ilgili bulgular:

'Bazen katlanamamak çok daha yararlıdır. İnsanı mevcut hâli değiştirmeye zorlar bak seni de zorlar. Buna katlanmaya devam etseydin belki de bu çıkışı asla yapamazdın. Öte yandan katlanamadı̆̆ın şey haksızlıktı. Haksızlığa karşı durdun sen.' (s. 82.)

Tabii bu Efe'nin hiç hoşuna gitmedi çünkü diğerleri de cesaretlerini toplayıp ona katılabilir, otoritesi sarsılabilir. Bu yüzden bizi küçük düşürmeye çalışıyor ama bir düşünün bakalım, doğru bildiğini savunan mı haklı yoksa efendim önünde boyun eğen mi? (s. 84)

Fotoğraf faslı bitince Defne gözlüğü bana uzattı. "Haydi, şimdi sıra sende. Burada durursan hepsini seyredersin.'” (s. 100) 
Ben sunum yaparken konuya kendim önem veriyorsam onu başkalarına anlatırken onlar da aynı önemi versin, her şeyi kavrasinlar isterim. Hata yapmamak için sıra ile konuşmaya ilgi kaybetmemeye karar vermiştik. (s. 143)

Araştırmaya konu olan eser incelendiğinde adalet değerinin, çoğunlukla "adil olma ve paylaşma " davranışları ile işlendiği görülmektedir.

\section{Dostluk Değeri}

TDK’ye (2019) göre dost kavramı; çok sevilen, güvenilen, yakın arkadaş, gönüldaş anlamlarına gelmektedir. Dostluk ise dost olma durumudur.

Dostluk değeri ile ilgili bulgular:

İnsan arkadaşları için çiğ tavuk bile yerken benim onlar için birkaç kafiyeli sözcük bulmam kabul edilebilir herhalde. (s.7)

Defne ben sinıfa girer girmez heyecanla yanıma gelmiş, akşam yaptı̆̆ araştırmayı teneffüste anlatacağını söylemiş ama ben Efe'nin bize baktığını görünce ona soğuk davranmaya çalı̧̧mıştım. Defne de ne olduğunu hemen anlamış, sanırım bu yüzden teneffüste yanıma gelmemişti. İçim içimi yiyor, Efe ile dışarı çılkı her şey yolundaymış gibi gülerken gözüm etrafta Defne'yi arıyor, kendimi berbat hissediyordum. (s.45)

'Hayır, bunu yapma Defne! Çok tehlikeli!' Ben sözümü bitirmeden Defne parmaklı̆̆ı dĭger tarafina geçmişti bile. Yaşadı̆̆ım panik duygusu harekete geçmemizi sağladı Defne görünmesin diye vücudumla ona siper olmaya çalıştım. (s.116)

Ateşim olduğunu söyleyince Defne elini alnıma koydu ve sonra hemen geri çekti. "Sen yaniyorsun, çok ateşin var. Hemen geri dönmeliyiz." (s. 124)

“Anne onun suçu yok. O dönelim demişti ama..." Annemin gözleri parladl. (s.131)

Ben de sana şöyle yanıt vereyim. Bir erkekle bir kız beraber çalışınca senin aklina sadece böyle fikirler geliyorsa bence daha çok okuyup baklş açını değisştirmelisin. Çünkü böyle düşünen biri ile kimsenin arkadaşlık etmek isteyeceğini sanmam. (s. 145)

Araştırmaya konu olan eser incelendiğinde dostluk değerinin, güven duyma, anlayışlı olma, dayanışma, sadık olma, vefalı olma ve yardımlaşma davranışları ile işlendiği görülmektedir. 


\section{Dürüstlük Değeri}

Dürüstlük, doğru ve dürüst olma durumu, doğru olana yakışır davranış, dürüstlük, adalet, düşüncenin gerçekle uyuşması durumu, yarg1 ve önermelerin gerçeğe uygun olması.” (TDK, 2019) şeklinde tanımlanmıştır.

Dürüstlük değeri ile ilgili bulgular:

Bugüne kadar yaptığım alışverişlerde herhangi bir şeyin fiyatını düşürebildiğim olmamıştı zaten ama bu defa epey yaklaşmıştım.( s.12)

... Aramızda böyle sizli bizli değil, senli benli bir ilişki vardı çünkü. Ama yabancıların yanında konuşma tarzı da ses tonu da biraz değişir annemin. (s.15)

Annemin bizimle beş yaşındaki çocukmuşuz gibi konuşmasının nedeni odama birilerinin girmesini sevmediğimi, bu yüzden ona kızacă̆ımı bilmesiydi. (s.18)

O kitabı karıştırmaya devam ederken ben de karnımı doyurmak istediğimi, açken iyi düşünmediğimi söyledim. (s.19)

Başlangıçta mektubu yazmanın imkânsız olduğunu düşünmüştüm ama insanın yanında Defne gibi bir proje arkadaşı olduğunda her şey kolaylaşıyor... hayatımda ilk kez ödev yapmaktan bu kadar zevk allyordum. (s.33)

Gözünden hiçbir şey kaçmayan bu insanla zaman geçirmek sıkıntılı oluyormuş. Hiçbir şeyi saklamamak en iyisi dürüstlükse işte sana dürüstlük: ... Sen dopaminin ne olduğunu bilmiyorsun. Valla bilmiyorum, derken genel kültürümle olmasa bile dürüstlüğümle övünebileceğimi hissediyordum. (s.35)

Tamam, annen yemek konusunda çok süper değildir ama beni savunmada bir numaradır. (s.41)

Benim açımdan da acıklı olan, benim de Efe'ye düşündüklerimi söyleyecek cesaretimin olmamaslydı. (s.45)

Her yerin bir havası var sanki. Arkadaşlarımla beraberken " kesin yapabilirim “, diye düşündügüum şeyler anneme söylerken güçlerini yitirir mesela. Annemin yanında başka, arkadaşlarımın yanında başka bir hava vardı sanki. s.44

Oysa Defne'ye terbiyesizlik yapan kendisiydi. Defne sadece doğru bildiğini söyleyerek ve bunu nazikçe yaparak ona yanıt vermişti. Belli ki tüm sinıfa kızmaktansa sadece Defne'ye öfkelenmek Efe'nin kolayıma gelmişti. (s.47)

Benim gibi kitaplarla pek haşır neşir olmayan insanları kalın kitaplar biraz ürkütür. (s.57) 
Ama bunların yetmeyeceği kesindi. Hele benim sinavlardan bile orta not alan zavall Ingilizce bilgimle olacak iş değildi. (s.60)

Hoşuna gitmese de kendince görev paylaşımı yapmıştı. Defne iyi bir insan diye geçirdim içimden. Bu görevi Efe ile yapıyor olsaydık, ben İstanbul uzmanı bile olsam gözlüğü benim takmama izin vermez, her işin en zevkli kısmını kendisi yapardl. (s.70)

Hem Defne diğerlerinden çok daha eğlenceli bir insandı ama onunla görüşmek demek Efe'nin oklarına hedef olmak demekti ve ben bununla uğraşmak istemiyordum. (s.78)

Aslında ben böyle bir tebrik değil de daha çok teşekkür gibi bir şey bekliyordum ama Defne'nin söylediklerinin doğru olduğunu hissettim. (s.81)

İ̧̧lerinden bizim fotoğraflarımızı çekenler oldu. Bunun için bizden izin istemediler. Biz de zaten gözlüğü vermediğimiz için kendimizi mahcup hissettiğimizde bizden izin alınmadan çekilen tüm fotoğrafları dünyanın en neşeli insanlarıymışı gibi gülümsedik. (s.100)

Bu yüzden bir sürelik organik pamuklu üretilmiş çamaşırları kimseye bağımlı olmadan pazarda satıyordu, hem de alış fiyatı ve satış fiyatın açık şekilde tezgâha yazarak. (s.103)

Defne o anda gülümseyerek başını kaldırmış, 'Haklısın, birileri doğruyu göstermekten vazgeçmemeli. Bazen seslerin yükselmesine kapanmayı öğrenmeliyim," demişti. (s.104)

Bu konağın sahibi miydi acaba? Sonra kendimi hayret ettim çünkü önceleri böyle şeyleri merak ettiğimi hiç hatırlamıyordum. (s.105)

'Ben daha önce hiç görmedim.' Defne buruk bir gülümseme ile bana baktt. Babamın işini kaybetmesinden sonra biz gördük. Ne yapalım kahramanlı öyle kolay olmuyor. (s.119)

Araştırmaya konu olan eser incelendiğinde dürüstlük değerinin, açık ve anlaşılır olma, doğru sözlü olma, güvenilir olma ve sözünde durma davranışları ile işlendiği görülmektedir.

\section{Öz denetim Değeri}

Öz denetim, daha önemli bir ereğe erişebilmek için bireyin tepkisel davranışlarını veya başka amaçlara yönelme eğilimini denetleyerek kısıtlamak olarak tanımlanmıştır (TDK, 2019). 
Öz denetim değeri ile ilgili bulgular:

Elime aldığım her İstanbul başlıklı kitabın yeni baskısı olup olmadığını babamın bana ödünç verdiği değerli telefonundan kontrol ediyordum... ama çok şükür ki tek elle tutarak havalı arayışlar yaparken telefonu da düşürmemiştim. (s.8)

Bu huyumdan nefret ediyorum. Bazen bir şeye öylesine odaklanıyorum ki başka noktalar gözümden kaçıveriyor. (s.12)

Çantamı arkama atıp sakinleşmeye çalıştım. Kendimi tutmaya çalışsam da sesim öfkeliydi. (s.16)

Cehaletimi daha fazla saklamaya karar verdim. (s.24)

Evde telefonumu kontrol ederek otururken kendime itiraf edemesem de Defne'den bir mesaj gelmesini bekliyordum ama hiçbir şey gelmedi. Yarım saat boş boş ekrana baktıktan sonra hata mı kabullenip bu işi çözmem gerektiğine karar verdim. Annemden Defnelerin nerede oturduğunu öğrenebilir sonra da onu ziyarete gidip olanlar hakkında konuşabilir belki özür bile dileyebilirdim. (s.47)

"Ben nasıl özür dileyeceğim mi bilemiyorum Defne. Gerçekten ayıp ettim.', (s.48)

Defne büyük bir maceranın eşiğindeymişiz gibi heyecanliydl. Oysa ben yaptığımızın kesinlikle yasak olduğunu düşünüyordum. (s.120)

Defne daha aşağı görmek için iyice içeri girdi. Ben korkmaya başlamıştım. Bir kere, tarihi bir eserin çevresinde izinsiz birtakım işler yaptyorduk. Öte yandan, biri bizi görecek olsa başımızın belaya gireceği kesindi. (s.120)

Defne bu kez gözlüğü benim çıkmam gerektiğini söyledi. Birilerinin peşinden koşmam gerekirse çok başarll olabileceğimi sanmıyordum ama yine de gözlüğü takıp başımı kaldırdım. (s.125)

Defne annemden yine özür diledi. Araları iyileşmişti. (s.133)

Evden çıkarken içimde bir sıkıntı vardı. Tamam, bizi taksiyle götürmesi iyi fikir olabilirdi ama ya biz konuşurken de yanımızdan ayrılmazsa ne olacaktı? Profesör daha ilk anda sırrı yazdığımızı düşünürdü. (s.136)

Araştırmaya konu olan eser incelendiğinde öz denetim değerinin, davranışlarını kontrol etme, davranışlarının sorumluluğunu üstlenme, öz güven sahibi olma, gerektiğinde özür dileme davranışları ile işlendiği görülmektedir. 


\section{Sabır Değeri}

Türkçe sözlükte sabır; acı, yoksulluk, haksılılı gibi üzücü durumlar karşısında ses çıkarmayarak bu durumların geçmesini bekleme erdemi, dayanç ve gelecek bir şeyi telaş göstermeden bekleme olarak açılanmıştır (TDK, 2019).

Sabır değeri ile ilgili bulgular:

Kitabı karıştırdı̆̆g için de sinirlendim ama kendimi tutmalıydım. (s.18)

... Arkasını döndü ve ufak çı̆̆llk attı. Sonra hemen elimi tuttu. Bir şeyden korkmuştu. Vücudu kendisini korumak ister gibi kamburlaştı. Sabirla beklemem gerekiyor belki.(s.26)

Özellikle dikkatimizi çeken hiçbir şey yoktu. Şimdi ne olacaktı? Bulmamız gereken her neyse ona erişmek için gerçekten çaba harcamanı gerekecekti. (s.112)

Araştırmaya konu olan eser incelendiğinde sabır değerinin, azimli olma, tahammül etme ve beklemeyi bilme davranışları ile işlendiği görülmekted

\section{Saygı Değeri}

Sayg1 değeri Türkçe Sözlükte, üstünlüğü, yaşl1lı̆ğ, yararl1lığ1, kutsallığg dolayısıyla bir kimseye, bir şeye karşı dikkatli, özenli, ölçülü davranmaya sebep olan sevgi duygusu, hürmet, ihtiram ve başkalarını rahatsız etmekten çekinme duygusu olarak geçmektedir (TDK, 2019).

Saygı değeri ile ilgili bulgular:

Misafirlere kapıdan ''Hoş geldiniz'” dedim. (s.12)

Defne'de heyecanlandı ve o da eve telefon edip benimle ödevi üzerine çallşmak için biraz daha süre istedi. Annesi sonunda kabul etti. (s.115)

Defne anneme gülümseyip ve defalarca 'Haklisınız,' diyerek bana doğru yaklaşmaya başladı. Odaya girdiğinde ne kadar heyecanlı olduğunu anlamamak için kör olmam gerekirdi. (s.132)

'Yahu hasta ziyareti yapıyoruz. Elimizde hiçbir şey yok."' Annem ben bunu da halledeceğim deyip bizi yalnız bırakarak tekrar merdivenlere yöneldi. Defne de şaşırmıştı. (s.138) 
Annem duyduklarının gizli anlamını fark etmese bile çok keyiflenmişti. Profesöre teşekkür etti. Sonra dışarı çıkmak için izin istedi. Bizi de profesörü fazla yormamamı gerektiğini söyleyerek uyardı. (s.141)

Araştırmaya konu olan eser incelendiğinde saygı değerinin, alçakgönüllü olma, başkalarına kendine davranılmasını istediği şekilde davranma, diğer insanların kişiliklerine değer verme, muhatabının konumunu, özelliklerini ve durumunu gözetme davranışları ile işlendiği görülmektedir.

\section{Sevgi Değeri}

Sevgi kavramı Türkçe Sözlükte, insanı bir şeye veya bir kimseye karşı yakın ilgi ve bağl1lık göstermeye yönelten duygu şeklinde tanımlanmıştır (TDK, 2019).

Sevgi değeri ile ilgili bulgular:

Gelenlerin arasında İstamata Teyze'nin olduğunu görünce keyfim iyice yerine geldi. İstamata Teyze ben seviyorum diye her gelişinde paskalya çöreği pişirip getirir. (s.12)

Defne de yanıma ilişti. Etrafa değil, artık bana bakıyordu. Hemen itiraz ettim.

"Bana bakmayı keser misin ne bulacak hemen bulalım, hadi."' (s.124)

"En sonunda uyandın. Nasılsin oğlum? Bakayım ateşin ne durumda? Fincanı yana koyup tavuk kokan elini anlıma dayadı. Oh, nihayet düşmüş. Çok korkuttun bizi. Bir akşam geç geleyim dedim, başıma açtıklarını bak!'” (s.131)

Annem bir anda sorgulama faslını unuttu. Hevesle, kupanın içindeki çorbayı kaşık kaşık ă̆zıma uzatmaya başladı. Çorba bittiğinde kendimi çok daha iyi hissediyordum. (s.132)

Annem bana ilaçlarımı uzatırken biraz sakinleşmiş gibiydi. Defne'nin saçlarını okşadl. "Güzel kizım kusura bakma, ben biraz üzüldüm. Yoksa sen de onun yaşıındasın senin de hesap edememen normal. (s.133)

Araştırmaya konu olan eser incelendiğinde sevgi değerinin, aile birliğine önem verme, fedakârlık yapma, güven duyma, merhametli olma, vefalı olma davranışları ile işlendiği görülmektedir.

\section{Sorumluluk Değeri}

Sorumluluk kavramı, bireyin kendi davranışlarını veya yetki alanına giren bir olayın neticelerini üstlenmesi durumu veya mesuliyet anlamına gelmektedir (TDK, 2019). 
Sorumluluk değeri ile ilgili bulgular:

Burada olmamın ve yaptığım araştırmanın nedeni Sosyal Bilgiler ve Türkçe ögretmenlerimizin el ele, kol kola vererek hazırladıklarl proje ödevi. (s.7)

Dün ikisi bir olup, konusu İstanbul olan eski bir kitap bulmamızı istemişler; ... Işste ben de bu yüzden okul çıkışı soluğu sahaflarda aldım. (s.8)

Sarayburnu'nun fotoğrafinın yanına açıklama yazalım. Sonra da mektubumuzu gönderelim. Öğretmenimiz elimize birer adres vermişti. Herkes bulduğu bilgileri bu adreslerde oturan ögrencilere mektupla bildirecekti. (s.31)

Daire numarasına bakllırsa ikinci ya da üçüncü Katta olmaltydllar. Önce "vazgeçsem mi?"' diye düşündüm ama sonra aklıma yaptığım haksızlık gelince yine utandım; hem ödevi de bitirmemiz gerekiyordu. (s.48)

...O araştırma sonuçlarını bugün mektupla özetleyip Galata'daki şu öğrenciye göndermeliydik. (s.78)

Eve dönmek zorunda kalmamızın nedeni aramalarına dönüş yapmayı hep erteledim, bu yüzden küplere binen annendi. Hakliydı da artık annem ne zaman ararsan telefona cevap verecek, bir dakika bile gecikmeyecektim. (s.85)

Kütüphanede olduğumuz için sesini kısmış olduğun telefonumu elime alınca annemin 5 dakika önce beni aramış olduğunu gördüm. Hemen onu aradım ama daha konuşmaya başlamamla, etrafindakilerin uyarllar ile karşılaşmam bir oldu. "Burası kütüphane çık dişarı da konuş sessiz oluyorlar eşliğinde anneme seni sonra arayacağım, deyip telefonu kapattım." (s.93)

Sonra meydanı süsleyen diğer sütunları da çekip fotoğrafları bastırmaya gittik. Mektubu yazma işini bu kez ben üstlendim. (s.107)

Araştırmaya konu olan eser incelendiğinde sorumluluk değerinin, kendine, çevresine, vatanına, ailesine karşı sorumlu olma; sözünde durma, tutarlı ve güvenilir olma, davranışlarının sonuçlarını üstlenme davranışları ile işlendiği görülmektedir.

\section{Vatanseverlik Değeri}

Vatanseverlik kavramı; yurtseverlik, yurtsever, vatansever olma durumu şeklinde tanımlanmıştır (TDK, 2019).

Vatanseverlik değeri ile ilgili bulgular: 
Sarayburnu'nun geçmişte nasıl bir yer olduğunu öğrenmemiz gerekiyordu. Tekrar Gülhane'ye kütüphaneye doğru yürümeye başladık. (s.28)

...Topkapı Saray’ı surları üzerine yapılmış eski bir köşk olduğu yazıyordu Padişahlar burada oturup caddeden geçen alayları seyrediyorlarmış. Alay Köşkü adı oradan geliyormuş. İşte bak, şurada yazıyor, İstanbul'da ilk yerleşim bu bölgede olmuş. Daha doğrusu öyle olduğu söyleniyor. Baksana, Evliya Çelebi de aynı efsaneden bahsetmiş. (s.29)

Defne 1700 yll önce gezdiğimiz sokaklarda nasıl bir yaşam olduğunu merak ediyordu. (s.34)

"Bak Evliya Çelebi'nin dediğine göre Fatih Sultan Mehmet İstanbul'u fethetmeden önce bu bölgede çarşı denilen alanlar varmış. Fetihten sonra Çarşı denilen bu sokakların üzeri kapatılmış. '”(s.58)

Üstelik tarih ile ilgili konuların ilginç olabileceği bugüne kadar aklıma bile gelmemişti. Tarihin ezberlenip unutulması gereken, gerçek hayattan bağımsız, bir sürü olaydan ibaret olduğunu sanıyordum... Her gün yürüdüğ̈̈m yolların, sokakların, caddelerin, gördüğüm binaların geçmişte yaşamış insanların hayatlarının bir parçası olduğunu hatta bizim bugün yaşadıklarımızın da gelecekte tarihin bir parçası olacağını daha yeni fark etmiştim. (s.77)

Başımı o yöne çevirince nefesim kesildi sanki. Ayasofya bugünkü gibi kiremit rengi değil de pirıl pırıl krem rengi gövdesi ile karşımdaydı. (s.73)

O zaman biz Çemberlitaş'ın önündeydik. O sütün çok eskiymiş baksana neredeyse 1700 yaşında. Üzerinde gördüğüm heykel de Apollon heykeliymiş. (s.89)

"Kubbenin etrafindaki melek resimleri de Bizans döneminden kalma. Ayasofya cami olarak kullanılmaya karar verilince üzerleri sıva ile kaplanmış." (s.91)

Kapalı çarşıya girip Cevahir bedesteni bulduk. Kartal, kapının üzerinde duruyordu. Fotoğrafinı çektikten sonra Çemberlitaş'a doğru ilerlemeye başladık. (s.94)

Zaten başlarında rehberlik yapan öğretmenlerin de sütün ile ilgili bir bilgisi olmadığı on saniyede anlayabiliyordunuz. Çünkü neredeyse üç bin yıllık esere baklp sadece "bu da yılanlı sütün'” diyorlardı. (s.98)

'Bu çocuklar tarihe değer verilmesini sağlayacak, Evliya Çelebi'nin bayră̆ını taşılyacaklar'” (s.141) 
“'Oysa burada yaşıyorsan, bu şehri güzelleştirmek için sen de elini uzatmalısın. Biz gönüllü rehber olmaya karar verdik. Sultanahmet'teki tarihi eserleri ziyaret edenlere bilgi vereceğiz. (s.146)

“Seni koruyacağız İstanbul; çünkü seni seviyoruz güzel şehrimiz." (s.148)

Araştırmaya konu olan eser incelendiğinde vatanseverlik değerinin çalışkan olma, dayanışma, kurallara ve kanunlara uyma, sadık olma, tarihsel ve doğal mirasa duyarlı olma, toplumu önemseme davranışları ile işlendiği görülmektedir.

\section{Yardımseverlik Değeri}

Yardımseverlik kavramı, bir kimsenin, başkalarının ihtiyacını karşılaması; hayırsever olma durumu, iyilikseverlik, hayırperverlik olma durumu olarak tanımlanmıştır (TDK, 2019).

Yardımseverlik değeri ile ilgili bulgular:

Bazen ben de arkadaşım Hakan'ın kız arkadaşına şiirler yazmasına yardımcı oluyorum. (s.7)

Delikanlı "peşime takılın" diyerek dışarı çıkınca acele ile dedeye teşekkür edip peşine takıldık. Birkaç karışık sokaktan geçtikten sonra gümüşçülerin olduğu bölgeye geçiş yapmadan durduk. Delikanlı kapının üzerindeki bir yeri işaret etti. "Aradığınız bu olmalı başka Kartal'da bilmiyorum Bir daha bu kadar dolambaçlı planlar yapacağınıza isteğinizi açıkça söyleyin. Haydi, bana eyvallah" dedi ve teşekkürlerimizi umursamadan çekip gitti. (s.67)

Adımlarımı daha da hızlandırdım. Defne'nin kolumu kontrol etmek istediğini, beni săg tarafta kalmaya yönlendirdiğini hissediyordum. (s.71)

Bunun üzerine Defne'ye 'içeriye girmeliyiz,' diye fisıldadım. Defne hemen koluna girip beni yönlendirmeye başladı. (s.74)

Arkadaşım zorbalığa uğrarken ben sesimi çıkarmadan put gibi duruyordum. Buna daha fazla devam edemezdim. "Sen ne diyorsun Efe? Burada neler oluyor'?? (s. 80)

Derse doğru yürürken Defne bana destek olmak ister sesini omuzuma dokundu. Daha önce öfkeden kıpkırmızı kesilmiş olan kendisi değildi sanki. (s.82)

Oturur oturmaz Defne kendisini aldı̆̆ gibi, bana da boş bir kâğıt vermiş, ilgili olabileceği düşündügüm her şeyi sayfa numarasını da belirterek not etmemi istemişti. (s.86) 
Defne'nin hiçbir şeyi atlamasını istemiyordum. Onu ayrıntıları hatırlatarak yardımci oldum (s.96)

Arayan annemdi. Teyzemin yardıma ihtiyacı olduğunu eve biraz geç geleceğini söyleyip kapattı. (s.109)

Hemen yerimden kalkmak istedim ama bunu yapar yapmaz başım tekrar döndü. Defne beni tutup tekrar oturttu. (s.133)

Defne'nin aşăğdan tuttuğu telefon ışığından faydalanıp merdiveni kullanarak yanina indim. (s.122)

Açmaya çalıştığı gözlerini bize odaklamaya çalıştl, sonra da yan tarafta Duran gözlüğ̈̈ne uzanmak istedi. Defne ondan önce davranıp gözlüğ̈̈ hemen kendisine uzattı. (s.138)

Araştırmaya konu olan eser incelendiğinde yardımseverlik değerinin, cömert olma, iş birliği yapma, merhametli olma, misafirperver olma, paylaşma davranışları ile işlendiği görülmektedir.

\section{Türkçe Dersi Öğretim Programı'nda Yer Alan Temalar ve Değerler Açısından Bulgular}

Araştırmaya konu olan eser incelendiğinde yukarıdaki bulgular bağlamında;

Erdemler; (ahlak, alçak gönüllülük, azim, cömertlik, dayanışma, dostluk, dürüstlük, güven, iyilikseverlik, kardeşlik, merhamet, paylaşma, sabır, sadakat, sayg1, sevgi, vefa, vicdanlı olmak, yardımlaşma), millî kültürümüz; (aile, büyüklerimiz, bayrak, gelenekler, kültürel miras, millî bayramlar, vatan, Türkçe, tarihi eserlerimiz), Milli Mücadele ve Atatürk; (fedakârlık, millî egemenlik, vatanseverlik), birey ve toplum; (ana dili, adalet, barış, dayanışma, empati, eşitlik, farklılıklara saygı, misafirperverlik, komşuluk ilişkileri, selamlaşma, toplumsal kurallar, vatandaşlık), okuma kültürü; (dil sevgisi), iletişim; (aile iletişimi, insanlarla iletişim), hak ve özgürlükler; (demokrasi, temel hak ve özgürlükler, toplumsal cinsiyet eşitliği / adaleti), kişisel gelişim; (çalışkanlık, empati, girişimcilik, öz denetim, öz eleştiri, öz güven, öz saygı, sorumluluk), bilim ve teknoloji; (girişimcilik), sağlık ve spor; (temizlik, adil oyun), duygular; (bağışlama, sevgi, takdir etme), sanat; (yenilikçi düşünme), vatandaşlık; (adalet, çalışma, eşitlik, paylaşma, sorumluluk) davranışları ile işlendiği görülmektedir.

\section{TARTIŞMA VE SONUÇ}

Teknolojik gelişmelerin sosyal ilişkileri zayıflatması ve aile içi iletişimin çekirdek aileyle sınırlı kalması değerlerin sağlıklı bir biçimde yeni nesle aktarımını zorlaştırmaktadır. Bu noktada görev dağılımının her ayağını 
güçlendirmek gerekir. Değer aktarımında sadece aile ya da okulun yapabilecekleri sınırlıken bu iki önemli unsurun yanına edebi eserleri de eklemek doğru olacaktır. Zira çocuklar, nitelikli bir edebi eser aracılığı ile başka kişilerin hayatlarını, yaşayışlarını, alışkanlıklarını, törelerini, düşünce yollarını keşfe çıkarak edebiyatın rehber olma (Oğuzkan, 2001: 5-6) özelliğinden faydalanmalıdır.

Bu çalışmada Birsen Ekim Özen'in Çelebi Zinciri adı eserinde, güncellenen Türkçe Öğretim Programı'nda adı geçen 10 kök değerden (adalet, dostluk, dürüstlük, öz denetim, sabır, sayg1, sevgi, sorumluluk, vatanseverlik ve yardımseverlik) hangilerinin yer aldığını tespit etmek ve bu değerlerin nasıl işlendiğini, hangi yöntemler aracılığı ile aktarıldığını belirlemek amaçlanmıştır.

Kitap incelendiğinde10 kök değerin tamamının yer aldığı görülmüştür. Kök değerler kategorisinde en çok yer alan değer, dürüstlük(20)tür. Palaz'ın (2019) çalışmasını oluşturan Birsen Ekim Özen'in incelenen altmış kitabından yedisinde de dürüstlük değerinin varlığı tespit edilmiştir. Çalışmayla benzer şekilde o kitaplarda da dürüstlük Çelebi Zinciri’nde olduğu gibi gerçeği gizlememek, yalan söylememek, hile yapmamak gibi farklı şekillerde tespit edilmiştir.

Dürüstlük kategorisinden sonra en sık görülen değer; yardımseverlik(13)’tir. Ağaoğlu (2018) Bahaeddin Özkişi’nin eserlerini öğretim programlarından ele alınan 24 değer açısından incelemiş ve en çok yardımseverlik, vatanseverlik, sayg1 değerleri tespit edilmiştir. Yardımseverlik değerinin sık yer alması açısından iki çalışmanın sonuçları benzerlik göstermektedir.

Dürüstlük ve yardımseverlikten sonra en çok rastlanan değer; vatanseverlik(12)'tir. Gümüş (2017) tarafindan yapılan Değerler Eğitimi Bağlamında Aytül Akal'ın Çocuk Romanlarının Analizi, adlı çalışmada vatanseverliğin en az rastlanan değer olduğunu görmekteyiz. Bu açıdan iki çalışmanın sonuçları örtüşmemektedir. Yine aynı çalışmada sevgi, sorumluluk ve saygı işlenme sıklığı en çok olan değerlerdir.

Söz konusu çalışmada öz denetimin(11) de çokça yer aldığ 1 görülmektedir. Akıncı (2019) da çalışmasında "Oğlum Ben Çocukken... Kızım Ben Çocukken... Kızım Nerdesin?” kitaplarında en sık rastlanan değerin öz denetim olduğu sonucuna varmıştır.

Öz denetimden sonra en fazla sorumluluk(8) kök değeri tespit edilmiştir. Kasap'ın (2019) Bekir Yıldız'ın çocuk kitaplarını değerler eğitimi açısından incelediği çalışmada en çok karşılaşılan, sorumluluk kök değeridir. Çalışmada sorumluluk ilk sıralarda yer almasa da karşılaşma sıklığı açısından üst sıralarda olduğu görülmektedir 
Değerler eğitimiyle ilgili birçok çalışmada en sık görülen sevgi(5) değerine Çelebi Zinciri adlı eserde çok sık rastlanmadığı görülmüştür. Behiç Ak'ın hikâyelerinin değerler eğitimi açısından incelenmesi isimli çalışmada Yeniay (2019), sevginin en çok rastlanan değer olduğu sonucuna ulaşmıştır. Benzer şekilde Özay (2019) da çocuk edebiyatı açısından Ülker Köksal'ın romanlarında değerler eğitimi isimli çalışmasında en çok sevgi değerine yer verildiğini tespit etmiştir. Sevgi değeriyle birlikte kitapta aynı sıklıkta sayg1(5) ve dostluk(5) değeri bulunmuştur.

Kitapta işlenme sıklığı en az olan değerler sabır(3) ve adalet(2) olarak karşımıza çıkmaktadır. Hikâyenin gidişatı doğrultusunda adaletin en az rastlanan değer olması Palaz'ın (2019) çocuk edebiyatı açısından Birsen Ekim Özen'in Eserleri ve Eserlerinde Yansıttığı Değerler Üzerinde İncelemeler, adlı çalışmayla örtüşmektedir. Yine benzer şekilde Akıncı'nın (2019) değerler eğitimi açısından Aytül Akal'ın çocuk romanlarını incelediği çalışmada da adalet değeri en az rastlanan değerdir. Nezihe Meriç'in çocuk kitaplarının değerler eğitimi açısından incelendiği çalışmada da en az yer alan değerin adaletli olma, değeri olduğu görülmüş̧ür (Çelikten, 2019).

Kitapta 10 kök değer kategorisinde olmayan değerlerin varlığı da dikkat çekicidir. Cesur olma, demokrasi, sır saklama, kanaatkâr olma, takdir etme, iyimserlik ve temizlik 10 kök değer dışında tespit edilen değerlerdir. Tespit edilen farklı değerlerin kitapta yer alması kitabın değerler açısından niteliğini arttırmıştır. Kitapta farklı değerlerin olması, edebi eserler aracılığı ile değer aktarımının gerçekleşmesini kolaylaştırır. Ancak sadece değerlerin yer alıyor olması bu noktada yetersiz olacaktır. Kitapta yer verilen değerlerin, uygun aktarım biçimleri ile okuyucuya kazandırılması da üzerinde durulması gereken önemli bir husustur.

Çelebi Zinciri adlı eserde tespit edilen değerlerin, aktarım biçimine bakıldığında yazar genel olarak doğrudan bilgilendirmek ve öğüt vermekten kaçınarak sezdirme yöntemini kullanmayı tercih etmiştir. Özellikle kitabın "Hoş geldin" başlığı altında bir şiirle başlıyor olması ve şiirin sonunda "Şimdi kapat kapağl ve düşün bunlarl / Hazır olursan eğer göreve/ Burada bekliyor olacağım hevesle." ifadeleri çocuğun kendisini kahramanın yerine koyup özdeşim kurmasına zemin hazırlamıştır. Kitapta yer alan kahramanlar doğrudan tanıtılmamış, kahramanların özellikleri sezdirilmiştir. Metnin bağlamından yola çıkarak kahramanlara yer verilmesi okuyucunun olayları içselleştirmesini kolaylaştıracaktır. Kitabın sonunun iyi bitmesi, verilen mücadelenin olumlu sonuçlanması, zorluklara karşı mücadele etmekten vazgeçilmediğinde başarının geleceğini göstermesi açısından önemlidir. 
Sonuç olarak söz konusu eserde, Özen'in değerler eğitimi açısından incelenen diğer kitaplarında olduğu gibi, MEB'in amaçları doğrultusunda öğrencilere kazandırılması gereken değerlerle örtüşen, öğrencilerin gelişimini olumlu yönde etkileyen değerlere rastlanmıştır. Yazarın çocukların ilgi ve ihtiyaçlarını göz önünde bulundurarak uygun aktarım biçimleri kullanmaya özen gösterdiği görülmüştür. Çocuklara örnek teşkil edebilecek kahramanlara sahip olması ve kimlik oluşum sürecindeki öğrencilere yol göstereceği düşünülerek Türkçe ders kitaplarında yazara ait bu eserin, Türkçe Dersi Öğretim Programı'nda yer alan temalar ve değerler açısından özellikle de Milli Kültürümüz ve kişisel gelişim temalarında kullanılabileceği sonucuna varılmıştır.

\section{ÖNERÍLER}

1. Bu tarz kitapların MEB' de kullanılacak tüm kitaplara örnek teşkil etmesi sağlanmalıdır. Sahip oldukları ulusal ve evrensel değerler sebebiyle değerler eğitimi sürecinde, okul kütüphanelerinde ve sınıf kitaplıklarında bulundurulmalı ve okuma derslerinde öğrencilere okutulmalıdır.

2. Özen'in kitaplarının içeriğinde MEB' in belirlediği değerleri barındırması sebebiyle, ders kitaplarında metin olarak kullanılması da değerler eğitimi açısından faydalı olacaktır

3. Kitapta olay örgüsünün zenginliği çocukların problem çözme yeteneğini güçlendirecektir.

4. Ders kitaplarında kullanılan metinler, değerler eğitimi bağlamında incelenerek üzerinde çalışılmış olan eserlerden seçilmelidir.

5. Kitabın içeriğinden yola çıkarak ve disiplinler arası ilişkiden yararlanarak, Sosyal Bilgiler dersinde de öğretmenler bu kitaptan tarih aktarımını vermesi açısından faydalanabilirler.

6. Bundan sonra yapılacak farklı araştırmalarda Birsen Ekim Özen'in kitapları Millı̂ Eğitim Bakanlığının kaynaklarında tespit edilen değerlerden farklı olarak yeni değerler ve farklı değer sinıflandırmaları doğrultusunda yeniden incelenebilir.

\section{KAYNAKÇA}

Ağaoğlu, Hatice Dilşad (2018). Bahaeddin Özkişi'nin Eserlerinin Değerler Eğitimi Açısından İncelenmesi, Yüksek Lisans Tezi, Karadeniz Üniversitesi Eğitim Bilimleri Enstitüsü Türk Dili ve Edebiyatı Eğitimi Bilim Dal1. Trabzon. 
Aktürk, Funda Gülfidan (2012). Çocukta Değerler Eğitimi Açısından Üzeyir Gündüz'ün Eserleri, Yüksek Lisans Tezi, Afyon Kocatepe Üniversitesi Sosyal Bilimler Enstitüsü Türkçe Eğitimi Anabilim Dalı. Afyon.

Çelikten, Fahri (2019). Nezihe Meriç'in Çocuk Kitaplarının Değerler Eğitimi Açısından İncelenmesi, Yüksek Lisans Tezi, Marmara Üniversitesi Eğitim Bilimleri Enstitüsü Türk Dili ve Edebiyatı Eğitimi Bilim Dalı. İstanbul.

Demir, Neslihan (2019). Değerler eğitimi açısından Necip Fazıl Kısakürek'e ait "Çile" adlı eserde kök değerlerin incelenmesi, Yüksek Lisans Tezi, Atatürk Üniversitesi Sosyal Bilimler Enstitüsü Felsefe ve Din Bilimleri Anabilim Dalı. Erzurum.

Derse, Gizem Ezgi (2019). 6. Sınıf Türkçe Ders Kitabında Yer Alan Metinlerin Değerler Eğitimi Açısından İncelenmesi ve Öğretmen Görüssleri Bağlamında Değerlendirilmesi, Yüksek Lisans Tezi, Eğitim, Van Yüzüncü Y1l Üniversitesi Bilimleri Enstitüsü Türkçe Eğitimi Bilim Dal1. Van.

Dilidüzgün, Selahattin (2007). Çağdaş Çocuk Yazını. Morpa Kültür Yayınları, İstanbul.

Gönen, Mehmet (2017). Çocuk Edebiyatı Yazarı ve Çizeri Olarak Feridun Oral'ın Çocuk Edebiyatımızdaki Yeri ve Eğitsel Değerler, Yüksek Lisans Tezi, Afyon Kocatepe Üniversitesi Sosyal Bilimler Enstitüsü Türkçe Eğitimi Anabilim Dalı. Afyon.

Kasap Nazan (2019). Bekir Yıldız'ın Çocuk Kitaplarının Değerler Eğitimi Açısından İncelenmesi, İnönü Üniversitesi Eğitim Bilimleri Enstitüsü Türkçe Eğitimi Anabilim Dalı. Malatya.

Kumbasar, Ezgi (2011). Muzaffer İzgü'nün Romanlarında Değerler Eğitimi Açısından İncelenmesi, Yayınlanmamış Yüksek Lisans Tezi, Karadeniz Teknik Üniversitesi Eğitim Bilimleri Enstitüsü Türkçe Eğitimi Anabilim Dalı. Trabzon.

MEB. (2018). Türkçe Dersi Öğretim Programı (İlkokul ve Ortaokul 1, 2, 3, $4,5,6,7$ ve 8. Sinıflar). MEB Yayınları, Ankara.

Memişoğlu, Simgenur (2019). Türkçe Öğretiminde Değerler Eğitimi Bağlamında Refik Halid Karay'ın Hikâyelerinin Analizi, Yüksek Lisans Tezi, Marmara Üniversitesi Eğitim Bilimleri Enstitüsü Türkçe Eğitimi Bilim Dalı. İstanbul. 
Oğuzkan, A. Ferhan (2001). Çocuk edebiyatt. Anı Yayıncılık. Ankara.

Saruhan, Palaz, Feyza (2019). Çocuk Edebiyatı Açısından Birsen Ekim Özen'in Eserleri ve Eserlerinde Yansittığı Değerler Üzerinde İncelemeler, Yüksek Lisans Tezi, Atatürk Üniversitesi Eğitim Bilimleri Enstitüsü Sınıf Eğitimi Bilim Dalı. Erzurum.

Şirin, Mustafa, Ruhi (2007). Çocuk Edebiyatına Eleştirel Bir Bakış. Kök Yayınları, Ankara.

Türk Dil Kurumu (2019). Türkçe Sözlük (Genişletilmiş Baskı). TDK, Ankara.

Ulusoy, Kadir ve Dilmaç, Bülent (2016). Değerler Eğitimi (4.Baskı). Pegem Akademi, Ankara.

Yeniay, Sinan (2019). Behiç Ak'ın Hikâyelerinin Değerler Eğitimi Açısından İncelenmesi, Yüksek Lisans Tezi, Necmettin Erbakan Üniversitesi Eğitim Bilimleri Enstitüsü Türkçe Eğitimi Bilim Dalı, Konya.

İnternet Kaynağı

URL4, https://www.unicef.org/turkey/crc/_cr23c.html (Erişim tarihi: 03.04.2019). 